\title{
Erratum to: Ebselen is a potent non-competitive inhibitor of extracellular nucleoside diphosphokinase
}

\author{
Lucia Seminario-Vidal • Catharina van Heusden • \\ Govindasamy Mugesh • Eduardo Rodolfo Lazarowski
}

Published online: 15 April 2011

(C) Springer Science+Business Media B.V. 2011

Erratum to: Purinergic Signalling

DOI 10.1007/s11302-010-9203-x

The original version of this article unfortunately contained a mistake. The spelling of the Lucia Seminario-Vidal and Catharina van Heusden names were incorrect.

The online version of the original article can be found at http://dx.doi. org/10.1007/s11302-010-9203-x.

L. Seminario-Vidal · C. van Heusden · E. R. Lazarowski $(\square)$ Cystic Fibrosis/Pulmonary Research and Treatment Center, University of North Carolina School of Medicine,

7017 Thurston-Bowles Building, CB 7248,

Chapel Hill, NC 27599-7248, USA

e-mail: eduardo_lazarowski@med.unc.edu

G. Mugesh

Department of Inorganic and Physical Chemistry, Indian Institute of Science,

Bangalore, India 